\title{
REVIEW
}

\section{Anatomy in the Third Reich: An Outline, Part 1. National Socialist Politics, Anatomical Institutions, and Anatomists}

\author{
S. HILDEBRANDT \\ Division of Anatomical Sciences, Office of Medical Education, \\ University of Michigan Medical School, Ann Arbor, Michigan
}

\begin{abstract}
Although it is known that anatomists working in Germany during the Third Reich have used bodies of victims of the National Socialist (NS) regime for dissection and research, a comprehensive history of the anatomy in the Third Reich has not yet been written. Recent studies of the history of German anatomy departments during this time period provide material for a first outline of the subject matter. A historical review can help with the formulation of ethical foundations in modern anatomy. From the outset, the NS regime sought to reorganize German universities according to NS leadership principles and political goals. Many German academics, especially physicians and among them anatomists, followed these intentions with a voluntary "self-alignment" that encompassed their professional actions as well as their ethics. Currently, political information is available for 111 of 178 anatomists. Thirty-eight of the anatomists were dismissed for racial or political reasons, among them 10 chairmen of anatomy, whereas 35 of the anatomists were politically active members of one of the NS organizations. Over $70 \%$ of the chairmen of anatomical departments in the time period from 1941 to 1944 were members of NS organizations. Anatomists, as so many other physicians and academics, belonged both, to the group of victims of the regime, i.e., those being dismissed from their positions for racial and political reasons, and to the group of supporters and sometimes active perpetrators of NS policies. Clin. Anat. 22:883-893, 2009. @ 2009 Wiley-Liss, Inc.
\end{abstract}

Key words: anatomy; National socialism; third Reich; bodies of the executed; ethics in anatomy

"... the same suspension of empathy that was so necessary a part of a physician's task was also, in other contexts, the root of all monstrosity."

(Pat Barker, 1995; The Eye in the Door)

"Is evil insanity? Or a really unpleasant version of sanity?"

(Laura Lippman, 2009; Life Sentences)

\section{INTRODUCTION}

Sixty years after the end of the Third Reich, the National Socialist (NS) regime in Germany, a comprehensive history of anatomy during this time period is still unwritten (Aumüller and Grundmann, 2002). Several studies on the topic have documented the involvement of anatomists in policies that are questionable from a modern ethical point of view, such as the use of the bodies of NS victims for

*Correspondence to: Sabine Hildebrandt, Division of Anatomical Sciences, Office of Medical Education, University of Michigan Medical School, 3767 Medical Science Building II, Catherine Street, Ann Arbor, MI 48109-0608, USA. E-mail: shilde@umich.edu

Received 22 April 2009; Revised 2 September 2009; Accepted 13 September 2009

Published online 16 October 2009 in Wiley InterScience (www. interscience.wiley.com). DOI 10.1002/ca.20872 
anatomical dissection. A closer analysis of the anatomy in the Third Reich may help anatomists to develop ethical guidelines for modern anatomy (Winkelmann and Schagen, 2009). The bioethicist Arthur Caplan (Caplan, 1994) recommends a very careful look at the details of this history as a foundation for analogies between the practices of then and now, an analysis which may lead to "instructive application" (Cahill, 1994) in contemporary anatomy, a discipline now considered a vehicle for teaching medical ethics (Dyer and Thorndike, 2000; Goddard, 2003).

The first part of this overview of the history of anatomy in the Third Reich analyzes the interaction between the NS government, universities, and anatomical institutions, as well as the relation between anatomists and politics. Specific questions are the extent of anatomists' NS membership and which anatomists were persecuted and dismissed by the regime. The special conditions of the NS judicial system will be explored that allowed for the increase in executions and bodies available to anatomical institutions. It will become apparent that anatomists were victims as well as supporters and sometimes perpetrators of NS policies.

\section{METHODS}

Literature was collected and examined on the following subject matters: German universities and Medical schools in general during the Third Reich, modern history of anatomical institutions and German Anatomy laws in the 19th and 20th Century. This study did not include work in original archives of the time period, but is based mostly on secondary literature. Wherever there was a source that was discussed controversially, e.g., the authenticity of Voss' diaries from Posen, an effort was made to verify or disprove the information. Literature was also gathered on the NS judicial system in relation to capital punishment and its procedures and relations with the anatomical institutions, as this background material is necessary to understand the unique situation of the availability of great numbers of bodies of NS victims for anatomical purposes.

To broaden the information on individual anatomists, biographical encyclopedias and obituaries were included as well as course catalogues of universities (Vorlesungsverzeichnisse) and original publications by anatomists. The duration and location of employment as well as any political information or dismissal for racial or political reasons were noted for chairmen of anatomical departments and other faculty. The documentation on anatomists was evaluated for their "NS-affiliation" as well as their "NSactivity." Thereby the category "NS-affiliation" denotes the membership in either the NSDAP (National Socialist Workers' Party) or any of its sub organizations, e.g., NS-Dozentenbund (NS lecturers league), NSD-Ärztebund (NS physicians union), NSKriegsopferversorgung (NS victims of war welfare), and any of the many others. It should be noted, that a membership even in the NSDAP itself did not signify that the person truly supported NS policies, as these memberships were often entered into only "pro forma," even by the individuals who disagreed with these policies (Giles, 1993, p 88). Thus, the category "NS-affiliation" is more a reflection of the pervasiveness of a quiet agreement with or capitulation before the strength of the NS regime and its influence. Any direct involvement in NS political work by anatomists was evaluated and categorized as "NS political activity."

A list was created of anatomists working in German anatomical institutions from 1933 to 1945, naming the "NS-affiliation" and/or "NS/activity" of individuals. Most of the anatomists had been trained as physicians. Tenured faculty members were included as well as some non-tenured assistants, mostly those who are of NS political importance or of professional interest for postwar Germany. Further listed are Austrian faculty members who served from 1933 to 1938 through the years of Austrofascism (Lichtenberger-Fenz, 1989, p 10/11). A "yes" under the "NS-affiliation" category denotes a membership in any NS organization as documented in the references. A "yes" for "NS political activity" indicates that the person was documented as active in SS (Schutzstaffel, NS elite corps) or SA (Sturmabteilung, brown shirts), NSDAP membership before 1933 , or that there are records of other definite endorsements of NS policies in the sources quoted, e.g., leadership roles in NS organizations, services as SS security service spy (Sicherheitsdienst of the SS) or speeches and publications. If there was any inconsistency in the references, the greatest likelihood of a "yes" or "no" in each category was evaluated and the "yes" or "no" furnished with a question mark to indicate the need for further corroboration. If there was no official documentation of NS activity, even though it was likely as judged by the references, a "no" was entered. This procedure ensured a conservative estimate of the extent of NS political involvement of anatomists. Results were gathered from this list, which can be made available to interested readers by the author.

The following references were used for these evaluations: Berlin: Berlin-Personalverzeichnis, 1932; Bauer, 1940; Schierhorn, 1986; Schottländer, 1988; Unger, 1998; David, 2004; Noack, 2007; Schagen, 2008. Bonn: Schierhorn, 1986; Unger, 1998; Kayßer, 2003; Forsbach, 2006. Breslau: BreslauVorlesungsverzeichnis, 1933; Wallraff, 1959; Ortmann, 1986; Andree, 1989; Grüttner, 2004. Danzig: Aumüller, 1991; Klee, 2003; Neander, 2006. Dorpat: Oberkofler and Goller, 1999. Erlangen: Wendehorst, 1993; Wittern, 1993. Frankfurt: Volbehr and Weyl, 1956; Schierhorn, 1986; Drabek, 1988; Hammerstein, 1989; Kasten, 1991; Grundmann and Aumüller, 1996; Klee, 2003. Freiburg: Volbehr and Weyl, 1956; Grün et al., 2002; Seidler and Leven, 2007. Giessen: Tonutti, 1957; Schierhorn, 1986; Jakobi et al., 1989; Unger, 1998; Grimm, 2004; Oehler-Klein, 2007. Göttingen: Zimmermann, 1991; Hinrichsen, 1992; Beushausen et al., 1998; Klee, 2003. Graz: Heindel, 1971; Scheiblechner, 2001, 2002. Greifswald: Greifswald-Vorlesungsverzeichnis, 1933; Degener, 1935; Fleischer, 1940; Wegner, 1956; Schneck, 1993; Klee, 2003. Halle: Aumüller and Grundmann, 
2002; Eberle, 2002. Hamburg: Volbehr and Weyl, 1956; Bussche, 1989a; Rothmaler, 1990; Grüttner, 2004. Heidelberg: Weckbecker, 1985; Schierhorn, 1986; Mussgnug, 1988; Eckart et al., 2006. Innsbruck: Schneider, 1944; Huter, 1970; Universität Innsbruck, 1992; Oberkofler and Goller, 1999. Jena: Aumüller, 1991; Zimmermann, 2000; Hossfeld et al., 2003; Klee, 2003; Redies et al, 2005. Kiel: KielVorlesungsverzeichnis, 1933; Zitzlsperger, 1944; Volbehr and Weyl, 1956; Aumüller, 1991; Aumüller and Grundmann, 2002. Cologne: Volbehr and Weyl, 1956; Ortmann, 1986; Golczewski, 1988. Königsberg: Bargmann, 1942; Bargmann and Scheffler, 1943; Ziesche, 1943; Aumüller, 1991; Lawrynowicz, 1999; Tilitzki, 2006. Leipzig: Becker et al., 2005. Marburg: Aumüller, 1991; Grundmann and Aumüller, 1996; Aumüller et al., 2001; Klee, 2003. Munich: München-Vorlesungsverzeichnis, 1932; Bauer, 1940; Lanz, 1950; Lippert, 1973; Böhm, 1995; Grundmann and Aumüller, 1996; Becker et al., 2005. Münster: Münster-Vorlesungsverzeichnis, 1932; Rothschuh, 1957; Toellner, 1980; Vieten, 1983; Grundmann and Aumüller, 1996; Aumüller and Grundmann, 2002; Dicke, 2004. Posen: Aly, 1994. Prague: Hlavácková and Svobodny, 1998; Hlavácková and Miskova, 2001. Rostock: Schuhmacher and Wischhusen, 1970; Klee, 2003. Strassburg: Kasten, 1991; Aumüller and Grundmann, 2002; Klee, 2003; Deichmann, 2005. Tübingen: Drews, 1992; Mörike, 1988. Vienna: Wien-Vorlesungsverzeichnis, 1937; Merinsky, 1980; Mühlberger, 1998; Hubenstorf, 1987, 1989, 2000; Aumüller and Grundmann, 2002; Neugebauer and Schwarz, 2004. Würzburg: Hayek, 1940a,b; Ebert, 1971; Münch, 1978; Wittstadt, 1982; Aumüller and Grundmann, 2002; Klee, 2003.

\section{Historiographic Background}

Although the involvement of physicians, including the anatomist August Hirt, in NS atrocities was first publicized by Alexander Mitscherlich and Fred Mielke in their documentation of the Nuremberg physicians' trials in 1947, and by Alice Platen-Hallermund's report on the murder of the mentally ill (Mitscherlich and Mielke, 1947, 1960; Platen-Hallermund, 1948), the topic was largely ignored by the German medical establishment for several decades after the war (Kater, 1987; Zimmermann, 1991; Beushausen et al., 1998; Baader, 1999). Apart from the generally prevalent German apathy concerning its NS history (Mitscherlich and Mitscherlich, 1977), this silence had two main reasons. First, there existed a widespread denial of any personal responsibility, which claimed that the medical atrocities had been committed by a few rare psychopaths under a regime of injustice that had fatefully and forcefully overtaken an otherwise rational medicine (e.g., Esch, 1951; Kater, 1989, p 222/223; Hofer and Leven, 2003). Second, academics had become "doubly homogenized" (Walther, 2008), first at the beginning of the Third Reich, when they were silent about the expulsion of their Jewish and oppositionally active colleagues and the usurpation of the universities by the NS regime, and later after the collapse of the NS re- gime, when they passed through "denazification" and reclaimed their positions in postwar Germany. This homogenization led to a silence of mutual solidarity, which was only broken with the advent of a new generation of physicians who felt the need to inquire more deeply into the history of medicine in the Third Reich (e.g., Baader and Schultz, 1980; Müller-Hill, 1984, 2004; Kudlien, 1985; Ärztekammer Berlin, 1989; Bleker and Jachertz, 1989; Kolb and Seithe, 1998).

Over the last 3 decades, studies of individual anatomists and anatomical institutions have been published in increasing numbers. Many German universities have evaluated their NS past, one of the earliest ones being the analysis of the University of Tübingen by Adam in 1977. These evaluations often include analyses of their medical departments (Bonn: Forsbach, 2006. Giessen: Oehler-Klein, 2007. Göttingen: Beushausen et al., 1998. Hamburg: Rothmaler, 1990. Heidelberg: Eckart et al., 2006. Jena: Zimmermann, 2000; Hossfeld et al., 2003; Redies et al., 2005. Marburg: Aumüller et al., 2001; Aumüller and Grundmann, 2002. Tübingen: Mörike, 1988; Drews, 1992; Schönhagen, 1992. Vienna: Malina and Spann, 1999). There is now enough material to attempt an outline of the general picture of anatomy during the Third Reich in all of Germany.

\section{Politics and Universities in NS Germany}

On January 30, 1933, the NSDAP under the leadership of Adolf Hitler became the ruling party in Germany and within months usurped all governing power. At this time, over half of Germany had been ruled by Prussian law and the rest by other local and state laws, which were quickly integrated into a general Reich legislation for all of Germany and its occupied territories (Deutsches Reich; Rothmaler, 1990; Koops, 2005; Forsbach, 2006). On March 12, 1938, Austria was annexed into the Reich, and parts of the Czech Republic followed on September 29, 1938. With the beginning and progress of the Second World War, other foreign territories became integrated into Germany for a period of time, including the Alsace, parts of Poland and the Baltics. Since 1934, all pre-existing and newly founded German universities (Strassburg, Posen, Prague, Dorpat) in these areas were under the direct governance of the Reich Ministry for Science, Education and Culture (Reichserziehungsministerium, REM), led by Bernhard Rust (Koops, 2005; Wechsler, 2005).

It was the declared aim of the REM to reorganize the universities according to the new authoritarian and NS oriented leadership concept (Führerprinzip) and to centralize their previously state-regulated administration (Böhm, 1995, p 181). This included the "cleansing" of the faculty of so-called "nonAryan" and oppositionally active persons, the alignment of science with NS doctrine and the utilization of all science for war purposes (Eberle, 2002). With rare exceptions, most German university faculties followed these intentions by a "self-alignment" (Selbstgleichschaltung) with these new policies 
(Ribhegge, 1985; Bussche, 1989a; Thom, 1990; Grundmann and Aumüller, 1996; Forsbach, 2006).

Many German academics had national-conservative inclinations, and as civil servants in the Prussian tradition did not question political authorities. Many were willing to give the new regime the benefit of the doubt and to remain silent (Franze, 1972, pp 55, 179, 182; Jansen, 1994; Böhm, 1995; Grundmann and Aumüller, 1996; Zimmermann, 2000). At the same time, anti-Semitism was pervasive in European societies including German universities (Geiss, 1988; Lichtenberger-Fenz, 1989, pp 5/6; Seidler, 2000, pp 71-74), and the dismissal of colleagues meant the opening up of opportunities in the very tight academic job market. Statistics from 1932 stated that only one out of seven medical lecturers had chances of becoming a full-time tenured professor in his lifetime (Kater, 1989). At the University of Berlin (Charité), every post forcefully vacated in 1933 was filled again within the following year (Walther, 2008).

Academic advancement in NS Germany depended to a large extent on some measure of loyalty to the regime. The REM, university officials and the NS lecturers' league (NS Dozentenbund) took part in varying degrees in recruitment decisions (Hartshorne, 1938; Scheiblechner, 2001). All candidates were checked by the secret service, so that no liberal or oppositionally active academic had any chance of advancement (Bussche, 1993). On the other hand, in anatomy academic excellence never ceased to be an important career factor. In the early years, nonNSDAP party members could still become department chairs, e.g., Hermann Stieve in Berlin, 1935 (Noack, 2007), while party membership and NS political activity alone without scientific merits could not guarantee advancement, as seen in the cases of Werner Blume in Göttingen or Johann Paul Kremer in Münster (Vieten, 1982; Höss et al., 1984; Giles, 1993, p 87; Böhm, 1995, p 450/584; Beushausen et al., 1998, p 197). Despite its aspirations of total control of the hiring process of new anatomical faculty, the REM rarely intervened directly. The recruitment of Ernst Theodor Nauck to the chair of anatomy in Freiburg was an unusual example of direct intervention by the REM in personnel decisions in anatomy (Seidler and Leven, 2007, p 505). Nauck was an active NS party member and spy for the SS security service but was also scientifically qualified for the job. Generally, most academics, especially physicians and the younger ones who still needed academic advancement, joined if not the NSDAP party itself then some other NS formation like the NS lecturers' league, the NS physicians union and others. Some politically active academics joined the SS or the SA voluntarily (Kater, 1989, p 132/133; Scheiblechner, 2001).

The major professional organization for physicians, Hartmannbund, collaborated with the government in the exclusion of so-called "non-Aryan members" from the society, so that within 6 years $95 \%$ of Jewish physicians were expelled and prohibited from treating "Aryan" patients (Rüther, 1997). Likewise, the renowned German research society Leopoldina excluded Jewish members, among them Albert Einstein and the anatomists Alfred Kohn, Franz Weidenreich, and Alfred Fischel (Gerstengarbe et al., 1995). The organization of pediatricians (Deutsche Gesellschaft fuer Kinderheilkunde) did not change its bylaws, but tolerated the withdrawal of $75 \%$ of its Jewish members by 1939 without protest (Seidler, 2000 , p 84). The professional society of anatomists, the Anatomische Gesellschaft, proceeded differently. It did not subscribe to the NS oriented leadership concept and did not introduce the exclusion of "nonAryan members" in their bylaws. Throughout the Third Reich it kept all those members in their listings, who had been dismissed due to NS racial laws (Schierhorn, 1986, p 959; Kühnel, 1989, p 53). The organization went through several controversies after 1933. Over the following years, politically active members, including Max Clara, Hans Petersen, Robert Wetzel, August Hirt, and later Eduard Pernkopf, who were backed by the REM, tried to transform the traditionally international society into a purely German entity and asked for the exclusion of "nonAryan" members. Philipp Stöhr Jr. of Bonn showed his protest against these voices by refusing to visit the society meetings during the later NS years (Fleischhauer, 1981). Other members were able to thwart the measures demanded by the National Socialists: Siegfried Mollier of Munich refused to even consider these colleagues' opinions in 1934. In the same year, Heinrich von Eggeling, secretary of the society, wrote personally to Hitler explaining why the formation of an exclusively German anatomical society was not desirable. When Pernkopf brought the question up again in 1943, it was Hermann Stieve who rebuked him severely (Kühnel, 1989).

\section{Laws and Body Procurement in NS Germany}

The REM was responsible for the anatomical institutions at the universities, including their body supply. Traditionally, the anatomical institutes used unclaimed bodies from hospitals, psychiatric institutions, and prisons, as well as the bodies of the executed for dissection. A Prussian law from 1877 and other local laws, e.g., Hamburg 1907 and 1919, granted the anatomical institutes the right to use the bodies of the executed for dissection, if the relatives did not claim the body. These laws were reinforced by Prussia on October 6, 1933, when anatomists from Halle (Stieve), Göttingen (Fuchs), and Jena (Böker) complained about a lack of compliance by the authorities with these laws. The laws were again reinforced by the REM on October 22, 1935, and on February 18, 1939 (Bussche, 1989b; Rothmaler, 1990; Forsbach, 2006; Noack, 2007). Later on anatomists frequently complained about the need to inform the families of the executed and about the relatives' opposition to dissection (Bussche, 1989b; Waltenbacher, 2008, p 218). Thus, in March 1943, it was decreed that the families of the executed did not have to be asked for consent to dissection and it was forbidden to release the bodies of Jews, Poles, and 
those executed for high treason to their relatives (Waltenbacher, 2008, p 219).

The German Reich had 240 independent correctional facilities, 22 of which were furnished with execution chambers. Between 1935 and 1937, these places of execution were centralized to initially 11 facilities, rising in number again to 22 by the end of the war. The measure was meant to increase the efficiency of the execution procedures (Noack, 2007). Each place of execution had certain anatomical institutes allocated to it, which were to receive bodies from these facilities, e.g., the universities of Greifswald and Berlin received bodies from the Berlin-Plötzensee facility, and Berlin also received bodies from the Brandenburg-Görden facility (Oberkofler and Goller, 1999; Noack, 2007; Waltenbacher, 2008; Waltenbacher T, Personal communication, December 16, 2008).

In 1937, the general method of execution was decreed to be decapitation by guillotine (Noack, 2007). Only special circumstances allowed for execution by shooting, for example, by the Gestapo (Geheime Staatspolizei, secret state police). Hanging was reserved for the crime considered most heinous, high treason, and the execution chambers were furnished with butcher hooks for hanging (Viebig, 2002; Noack, 2007; Waltenbacher, 2008). The Gestapo also performed hangings with mobile gallows that were transported to the place of execution (Drews, 1992; Schönhagen, 1992). With the escalating political situation during the war the legal definition of high treason came to encompass, aside from political opposition, actions like black marketeering, listening to enemy radio, the telling of political jokes, and so-called Rassenschande (racial defilement). In addition, forced laborers from Poland and other countries were victims of special laws that led to frequent executions (Volksschädlingsverordnung September 5, 1939; Kriegswirtschaftverordnung September 4, 1939; Polenstrafrecht December 4, 1941; Rothmaler, 1990; Beushausen et al., 1998, p 233ff; Oberkofler and Goller, 1999; Form and Schiller, 2005). The verdicts of capital punishment were declared by the Volksgerichtshof (People's Court), the Reichskriegsgericht (Reich Court martial or military court), and by Sondergericht (special NS courts) (Noack, 2007, p 11). Prison officials informed anatomical institutes about an imminent execution beforehand, so that the institute could send an emissary to collect fresh tissues or the whole body itself. Frequently the prisons were planned with rooms set aside for the needs of the anatomists. Transportation of the bodies was usually by special vans owned by the anatomical institutes (Waltenbacher, 2008).

\section{Anatomical Institutions from 1933 to 1945}

In 1933, 24 German universities had anatomical departments. The Austrian universities of Vienna, Graz, and Innsbruck, as well as the Czech university of Prague became German in 1938. During the war, Strassburg (Alsace), Posen (Poland), and Dorpat (Tartu, Estonia) were added, bringing the total to 31 (see also: Müller-Wille, 1991). The universities of
Strassburg, Posen, and Prague were conceptualized as "Reichsuniversitäten" (universities of the German Reich) with a special bulwark function against "foreign cultural influences" and emphasis on the supremacy of the German people (Piotrowski, 1984; Wróblewska, 2000, p89; Baechler et al., 2005). Little information is available for Dorpat (Tartu), which was the least functional of the "Reichsuniversitäten" (Piotrowski, 1984, p 471). Overall, the anatomical departments were of varying size, with one chair for gross anatomy and sometimes an additional one for histology and/or embryology, as well as several more tenured and untenured positions and assistants. The latter were either medical students or medical residents. While German student numbers dropped from 25,000 in 1933 to 16,000 in 1939 due to the expulsion of Jewish and female students and regulation of student numbers by the REM, they rose again to 40,000 in 1944, as doctors were needed in the field of war (Aumüller et al., 2001). At the same time, faculties were generally smaller during the war years as younger faculty members had to serve in the military.

\section{Anatomists and Politics}

At this point, political data are available for 111 of 178 anatomists working in German anatomical departments from 1933 to 1945, i.e., political information is missing in $38 \%$. Thirty-five (20\%) of the 178 were active National Socialists (NS-affiliation/activity: Yes/Yes, Yes/Yes?), 28 (15\%) were non-active members of NS affiliations (Yes/?, Yes/No), 10 (6\%) were definitely or most likely not members of any NS affiliation (No/No, ?/No), and 38 (21\%) were dismissed for political and racial reasons. The percentage of National Socialists in higher university positions increased in the later years of the NS regime. There were 37 chairmen of German anatomical departments from 1941 to 1944, the time period of Germany's largest geographical expansion. Of these, only Hermann Stieve (Berlin) and Otto Grosser (Prague) are known to have not had any official NS affiliations. Stieve was a right-wing national-conservative, who generally kept his distance to the NS regime (Schagen, 2005; Noack, 2007), while Grosser was quite sympathetic of NS politics (Hlavácková and Mísková, 2001). Fifteen chairmen were party members and politically active to varying degrees, while 12 were members of one of the NS affiliations, but not known to be politically active. This latter group included persons with a known dislike for the NS system, e.g., Philipp Stöhr jr. (Bonn: Forsbach, 2006), Ferdinand Wagenseil (Giessen: Schmidt, 1993; Unger, 1998; Oehler-Klein, 2007), and Alfred Benninghoff (Marburg: Aumüller et al., 2001). Also a member of this group was Hermann Voss, who had joined the party reluctantly, but according to his diary, was nevertheless a fervent anti-Semite and hated Slavs (Posen: Aly, 1994). No political information was available for 8 chairmen (Ernst Weinberg, Dorpat; Hans Schreiber, Frankfurt am Main; Wilhelm Pfuhl, Greifswald; Franz Stadtmüller, Cologne; Robert Heiss, Königsberg; Walther Vogt, Munich; Maximilian Watzka, Prague; Victor 
Patzelt, Vienna). In conclusion, over $70 \%$ of all department chairs from 1941-1944 were members of one of the NS affiliations, and more than half of those were politically active.

Of the politically active anatomists, the SS officers August Hirt and Johann Paul Kremer stand out because they were prosecuted for crimes against humanity after the war. Hirt was the Dean of the Strassburg Medical School. Newly recruited faculty members of the Reichsuniversitäten Prague, Strassburg, and Posen were chosen for their NS political convictions. They tended to see themselves as "political soldiers in university gowns" (Piotrowski, 1984; Wróblewska, 2000, p 138; Uhlmann, 2002, p 283). Many of the Strassburg academics were SS officials, including Hirt's assistants Anton Kiesselbach and Karl Wimmer. The University of Strassburg was of special interest for the NS regime, as it supported several medical research projects of military importance (Kater, 1974; Deichmann, 2005; Wechsler, 2005). Hirt's early career had focused on fluorescence microscopic research, a technique he had invented in the 1920's in collaboration with Philipp Ellinger, a Jewish pharmacologist. After Ellinger was dismissed by the NS regime in 1933, Hirt claimed the method as his own (Kasten, 1991; Masters, 2008). During his tenure at Strassburg he started developing research proposals deemed "relevant for the war effort." These projects supported the eugenic thinking of Heinrich Himmler, Reich Minister of the Interior, who financed Hirt's research through the Ahnenerbe organization (Kater, 1974; Kasten, 1991). Hirt carried out lethal medical experiments with mustard poison gas on prisoners at the Natzweiler concentration camp, with help from Wimmer and Kiesselbach. Another project was the creation of a "Jewish skeleton" collection, for which Hirt had 86 Jewish prisoners transported from Auschwitz to the Natzweiler concentration camp, where they were murdered with cyanide gas in August of 1943 (Mitscherlich and Mielke, 1947, 1960; Kater, 1974; Lachman, 1977; Pressac, 1985; Deichmann, 2001, p 352-356; Steegmann, 2005a,b; Wechsler, 2005; Lang, 2007).

Johann Paul Kremer of Münster was the only anatomy professor who worked in an extermination camp, Auschwitz. He was involved in selections at the ramp and pursued research on the effects of starvation on the human body. For these studies, he selected prisoners of interest before their execution by intracardial phenol-injection and harvested their tissues immediately postmortem. He kept a diary during his months at Auschwitz, which later became one of the first documents providing proof for the involvement of physicians in NS atrocities (Vieten, 1982; Höss et al., 1984; Lifton, 1986, pp 333/334).

\section{The Dismissed}

Thirty-eight of the 178 anatomists were expelled from German universities as a result of the application of the new laws concerning the reformation of the civil service (Gesetz zur Wiederherstellung des Berufsbeamtentums). The first of these laws was ratified on April 7, 1933, and stipulated the dismissal of so-called
"non-Aryan" civil servants as well as politically suspect persons, e.g., communists. Over the course of the next 6 years, these laws came to include persons married to "non-Aryans" and social democrats, and were vague enough to be applicable to anybody whom the authorities wanted to eliminate from the university system, usually for political reasons (Mussgnug, 1988, p 95; Uhlig, 1991, p 143ff; Grüttner and Kinas, 2007, p 133ff; Seidler and Leven, 2007, p 442). The dismissals started in 1933, and continued to the early war years, sometimes phrased as "early retirement," e.g., in the case of Alfred Kohn (Körting, 1968). Of the 38 faculty members of anatomical departments who were victims of the so-called "purification" process, 10 were chairmen of anatomy: Hans Bluntschli (Frankfurt am Main), possibly Bruno Henneberg (Giessen, sources unclear), Heinrich Poll (Hamburg), Johannes Brodersen (interim, Hamburg), Otto Veit (Cologne), Walther Berg (Königsberg), Alfred Kohn (Histology, Prague), Julius Tandler (Vienna), and his successor Gustav Sauser. Wilhelm von Möllendorf (Freiburg), a social democrat and opponent of the NS regime, left the country voluntarily in 1935, accepting a chair position in Zurich, Switzerland (Seidler and Leven, 2007). The other 28 dismissed anatomical faculty members included professores emeriti and assistants, among them the anatomist and anthropologist Franz Weidenreich (Freiburg) and the anatomist and racial hygienist Karl Saller (Göttingen). Weidenreich, who went on to discover the "Peking man," was dismissed because he was a Jew (officially: retired, Weckbecker, 1985, p 288), Saller because he had formulated a dynamic theory of race that ran counter to accepted NS positions on the subject (Saller, 1961; Kudlien, 1985; Proctor, 1988; Weingart et al., 1988; Lüddecke, 1995; Beushausen et al., 1998; Schafft, 2004, p 227ff).

The fate of the dismissed anatomists depended in part on their age, their professional status, and the enmity that the NS regime showed for so-called "non-Aryans" and opponents of the regime (Schierhorn, 1986). Some anatomists went on to new academic positions in other countries, e.g., Bluntschli (Cener, 1990) and Wolff-Heidegger in Switzerland, Paul Glees and Werner Jakobson in England, Georg Politzer in India (Politzer, 1954), and Carla ZawischOssenitz and Ernst A. Scharrer in the US (Bargmann, 1966). Others survived the NS period remaining in Germany and working as private practitioners, e.g., Hermann Höpke as a physician, Gustav Sauser as a pharmacologist, and Karl Saller as a homeopath. Julius Tandler died of natural causes soon after his dismissal (Goetzl and Reynold, 1944; Sablik, 1983), while the 72-year-old Heinrich Poll died shortly after arriving in Swedish exile in 1939. His wife Clara Poll committed suicide two months later (Braund and Sutton, 2007). The 76-year-old Alfred Kohn survived an imprisonment in the Terezin concentration camp (Theresienstadt) from 1943 to 1945.

\section{DISCUSSION}

One of the first aims of the NS regime was the total control of universities, and with them Anatomi- 
cal Departments, in terms of ideology and personnel. While the dismissal of racially and politically unwanted anatomical faculty was complete within a few years, the regime did not succeed in the control of recruitment of new faculty in anatomy. Rare political appointments were coupled with academic competence of the candidate. The professional society of anatomists was able to defend its independence from the NS regime, in contrast to other academic professional societies. A unique relationship between the government and the Anatomical Institutions existed in the provision of bodies of the executed for dissection. This issue will be further explored in part 2 of this study.

In terms of NS affiliation and political activity, German anatomists seem to reflect the same higher than the average of the population pattern of NSDAP membership that has been reported for German physicians in general at 44.8\% (Bussche, 1989a; Kater, 1989; Forsbach, 2006, pp 39, 40). While the present study uses a slightly wider definition of NS affiliation (any NS membership, not NSDAP membership exclusively), it is certain that at least $30 \%$ of the anatomists held an NS membership (most of them NSDAP). Seventy percent of the chairmen from 1941 to 1944 held an NS affiliation, and about half of those were politically active. Heiber claims that anatomists were particularly active in NS politics, as they had more time to spend on extracurricular activities compared to their clinical colleagues, who had patients to care for on private wards (Heiber, 1991, p 94). To validate this claim, one would have to compare the political involvement of anatomists to other theoretical basic medical scientists like physiologists and to individual clinical disciplines, a study that has not been done yet.

Thirty-eight (21\%) of the 178 anatomists were dismissed. This number corresponds to the results of a study by Grüttner and Kinas (2007, p 139), who reported that overall $19.3 \%$ (1145 of 6140 ) of all university faculty members listed in Germany in 1933 were dismissed. If anatomists lamented the expulsion of their racially or politically persecuted peers, they generally did not do so publicly (Thom, 1990). In some cases anatomists tried to keep fellow faculty members as long as possible in their positions, e.g., Otto Veit in Cologne (Ortmann, 1986) and Karl Saller in Göttingen (Saller, 1961, p 47), but ultimately the NS authorities ignored such efforts. There is only one reported case of a physician, the pharmacologist Otto Krayer, not accepting the post vacated by a dismissed colleague, Philipp Ellinger, and protesting against the dismissal. As a consequence he had to leave Germany for the US (Harvard University, Boston; Walther, 2008, p 48). Aumüller (1991) reports that Günther Hertwig, Rostock, was the only anatomist known to him to have openly voiced opposition against the NS regime. In consequence, Hertwig's professional career was halted and he had to work in a subservient position, the only one available and provided for by Stieve in Berlin, until the end of the war (see also Drabek, 1988, p 56). Generally, if anatomists protested against authorities and regulations at all, then in connection with factual problems concerning the body supply or matters of the medical curriculum (Kästner, 1993). Especially the autocratic Hermann Stieve was known for strong opinions concerning the teaching of anatomy and led several controversial discussions with the university administration (David, 2004, pp 237/ 238; Noack, 2007; Winkelmann and Schagen, 2009). He gave employment to two anatomists who were in conflict with their politically active NS chairmen at other universities. Besides Günther Hertwig in conflict with Kurt Neubert in Rostock (Aumüller, 1991) this was Otto Popp with August Hirt in Greifswald (Schneck, 1993).

This is a first attempt to gather presently existing information on the Anatomy in the Third Reich and provide an overview of the subject matter. While much information is available, this study has to be preliminary due to the fact that some universities have not yet explored their history and archives of the time period. Its aim is not to denounce, but to elucidate the facts in order to learn from history, to realize one's potential fallibility and to find guidelines for the future (Mitscherlich and Mielke, 1947; Kater, 1987 , p 56). "We may not be able to judge [the NS anatomists], but we can and must set desirable standards of consciousness and behavior and aspire to live up to them" (Cohen and Werner, 2009).

Looking at the connection between politics and the anatomists in the Third Reich, it can be said in conclusion that anatomists, as so many other physicians and academics, belonged both, to the group of victims of the regime, i.e., those being dismissed from their positions for racial and political reasons, and to the group of supporters and sometimes active perpetrators of NS policies. Anatomists as a group did not offer apparent opposition to NS policies but were able to retain some independence in their personnel politics and professional society.

\section{REFERENCES}

Adam DU. 1977. Hochschule und Nationalsozialismus. Die Universität Tübingen im Dritten Reich. Tübingen: JCB Mohr (Paul Siebeck). p 1-240.

Aly G. 1994. The Posen diaries of the anatomist Hermann Voss. In: Aly G, Chroust P, Pross C, editors. Cleansing the Fatherland. Nazi Medicine and Racial Hygiene. Baltimore: The Johns Hopkins University Press. p 99-155.

Andree Ch. 1989. Die Ausschaltung jüdischer Mediziner der Universität Breslau und die Gleichschaltung der Ärzteschaft durch den Reichsärzteführer Gerhard Wagner. In: Bossle L, Keil G, Menzel J], Schulz EG, editors. Nationalsozialismus in Schlesien. Sigmaringen: Jan Thorbecke Verlag. p 105-120.

Aumüller G. 1991. Die Anatomie in der NS-Zeit. Fachschaft Medizin der Philipps-Universität Marburg: "bis der langersehnte Umschwung kam." Von der Verantwortung der Medizin unter dem Nationalsozialismus. Marburg. p 87-112.

Aumüller G, Grundmann K. 2002. Anatomy during the third Reich: The Institute of Anatomy at the University of Marburg, as an example. Ann Anat 184:295-303.

Aumüller G, Grundmann K, Krähwinkel E, Lauer H, Remschmidt H. 2001. Die Marburger Medizinische Fakultät im "Dritten Reich." München: K.G. Saur. p 1-736.

Baader G. 1999. Die Erforschung der Medizin im Nationalsozialismus als Fallbeispiel einer Kritischen Medizingeschichte. In: Bröer R, editor. Eine Wissenschaft emanzipiert sich. Die Medizinhistoriog- 
raphie von der Aufklärung bis zur Postmoderne. Pfaffenweiler: Centaurus-Verlagsgesellschaft. p 113-120.

Baader G, Schultz U. 1980. Medizin und Nationalsozialismus. Tabuisierte Vergangenheit- Ungebrochene Tradition? Dokumentation des Gesundheitstages Berlin 1980. Berlin: Gesundheit mbH.

Baechler C, Igersheim F, Racine R. 2005. Les Reichsuniversitaeten des Strasbourg et de Poznan et les Resistances Universitaires 1941-1944. Strassbourg: Presse Universitaires de Strasbourg. $p$ $1-276$.

Bargmann W. 1942. Über Kernsekretion in der Neurohypophyse des Menschen. Z Zellforsch 32:394-400.

Bargmann W. 1966. Ernst A. Scharrer zum Gedächtnis. Anat Anz 119:119-127.

Bargmann W, Scheffler A. 1943. Über den Saum des menschlichen Darmepithels. Z Zellforsch 33:5-13.

Barker P. 1995. The Eye in the Door. London: Plume-Penguin. p 165.

Bauer K. 1940. Über das Grundnetz der menschlichen Grosshirnrinde. Z Zellforsch 30:751-768.

Becker C, Feja Ch, Schmidt W, Spanel-Borowski K. 2005. Das Institut für Anatomie in Leipzig. Eine Geschichte in Bildern. Leipzig: Sax-Verlag. p 1-64.

Berlin Ä. (ed.) 1989. Der Wert des Menschen: Medizin in Deutschland 1918-1945. Berlin: Edition Hentrich. p 1-388.

Berlin-Personalverzeichniss: Personal- und Vorlesungsverzeichnisse der Friedrich-Wilhelms Universität Berlin 1932/33-1944/45.

Beushausen U, Dahms H-J, Koch T, Massing A, Ortmann K. 1998. Die medizinische Fakultät im Dritten Reich. In: Becker $\mathrm{H}$, Dahms $\mathrm{H}-\mathrm{J}$, Wegeler C, editors. Die Universität Göttingen unter dem Nationalsozialismus. München: K.G. Saur. p 183-286.

Bleker J, Jachertz N. (eds.) 1989. Medizin im "Dritten Reich." Köln: Deutscher Ärzteverlag. p 1-244.

Böhm H. 1995. Von der Selbstverwaltung zum Führerprinzip. Die Universität München in den ersten Jahren des Dritten Reiches (1933-1936). Berlin: Duncker \& Humblot. p 1-649.

Braund J, Sutton DG. 2007. The case of Heinrich Wilhelm Poll (1877-1939): A German-Jewish geneticist, eugenicist, twin researcher and victim of the Nazis. J Hist Biol 41:1-35.

Breslau-Vorlesungsverzeichnis: Vorlesungs- und Personalverzeichnis 1933-1939.

Bussche H van den. (ed.) 1989a. Medizinische Wissenschaft im "Dritten Reich." Kontinuität, Anpassung und Opposition an der Hamburger Medizinischen Fakultät. Berlin/Hamburg: Dietrich Reimer Verlag. p 1-473.

Bussche H van den. 1989b. Im Dienste der "Volksgemeinschaft": Studienreform im Nationalsozialismus am Beispiel der ärztlichen Ausbildung. Berlin/Hamburg: Dietrich Reimer Verlag. p 1-261.

Bussche $\mathrm{H}$ van den. 1993. Personalpolitik und akademische Karrieren an der Hamburger Medizinischen Fakultät im "Dritten Reich." In: Grau G, Schneck P, editors. Akademische Karrieren im "Dritten Reich." Beiträge zur Personal- und Berufungspolitik an Medizinischen Fakultäten. Berlin: Pegasus. p 19-38.

Cahill LS. 1994. Lessons we have learned. In: Michalczyk JJ, editor. Medical Ethics and the Third Reich: Historical and Contemporary Issues. Kansas City: Sheed \& Ward. p 213-216.

Caplan AL. 1994. The relevance of the Holocaust to bioethics today. In: Michalczyk JJ, editor. Medical Ethics and the Third Reich: Historical and Contemporary Issues. Kansas City: Sheed \& Ward. $p$ 3-12.

Cener F. 1990. Der Anatom Hans Bluntschli-1877-1962. Zürich: Juris Druck + Verlag. p 1-123.

Cohen J, Werner RM. 2009. On medical research and human dignity. Clin Anat 22:161-162.

David H. 2004. "... es soll das Haus die Charité heissen...." Band 1. Berlin: akademos Wissenschaftsverlag. p 1-460.

Degener H. (ed.) 1935. Degener's Wer ist's. Berlin: Verlag Hermann Degener. p 1-1833.

Deichmann U. 2001. Flüchten, Mitmachen, Vergessen. Chemiker und Biochemiker in der NS-Zeit. Weinheim/New York: WileyVCH. p 1-596.

Deichmann U. 2005. Biochemie an den Reichsuniversitäten in Strassburg und Posen. Wissenschaft, Betrug und Verbrechen.
In: Baechler C, Igersheim F, Racine P, editors. Les Reichsuniversitäten des Strasbourg et de Poznan et les Resistances Universitaires 1941-1944. Strasbourg: Presse Universitaires des Strasbourg. p 127-141.

Dicke JN. 2004. Eugenik und Rassenhygiene in Münster. Berlin: Weissensee Verlag. p 1-167.

Drabek A. 1988. Die Dr. Senckenbergische Anatomie von 1914 bis 1945. Hildesheim: Georg Olms AG. p 1-160.

Drews U. 1992. Die Zeit des Nationalsozialismus am Anatomischen Institut in Tübingen: Unbeantwortete ethische Fragen damals und heute. In: Peiffer J, editor. Menschenverachtung und Opportunismus. Zur Medizin im Dritten Reich. Tübingen: Attempto. p 93-100.

Dyer GS, Thorndike ME. 2000. Quidne mortui vivos docent? The evolving purpose of human dissection in medical education. Acad Med 75:969-979.

Eberle H. 2002. Die Martin-Luther-Universität in der Zeit des Nationalsozialismus 1933-1945. Halle (Saale): Mdv Mitteldeutscher Verlag. p 1-539.

Ebert C. 1971. Die Personalbiographien der Ordinarien und Extraordinarien der Anatomie mit Histologie und Embryologie, der Physiologie und der Physiologischen Chemie an der Medizinischen Fakultät der Julius-Maximilians-Universität Würzburg. Dissertation, Erlangen-Nürnberg.

Eckart WU, Sellin V, Wolgast E. 2006. Die Universität Heidelberg im Nationalsozialismus. Heidelberg: Springer. p 1-1278.

Esch P. 1951. Werden, Vergehen und Wiedererstehen der medizinischen Fakultät der Universität Münster (Westfalen). 25 Jahre Medizinische Fakultät der Universität Münster. Münster: Verlag Aschendorff. p 13-16.

Fleischer H. 1940. Über ein regelmässig vorhandenes Ganglion accessorium trigemini und seine Lage im Cavum trigemini. Z Anat Entwicklungsgesch 110:755-766.

Fleischhauer K. 1981. In memoriam Philipp Stöhr jr. Anat Anz $150: 239-247$.

Form W, Schiller Th. 2005. Politische Justiz in Hessen. Die Verfahren des Volksgerichtshofs, der politischen Senate der Oberlandesgerichte Darmstadt und Kassel 1933-1945 sowie Sondergerichtsprozesse in Darmstadt und Frankfurt/M. (1933/34). N.G. Marburg: Elwert Verlag. p 1-1165.

Forsbach R. 2006. Die Medizinische Fakultät der Universität Bonn im "Dritten Reich." München: R. Oldenbourg Verlag. p 1-767.

Franze M. 1972. Die Erlanger Studentenschaft 1918-1945. Würzburg: Kommisionsverlag Ferdinand Schöningh. p 1-440.

Geiss I. 1988. Geschichte des Rassismus. Frankfurt am Main: Suhrkamp. p 1-374.

Gerstengarbe S, Hallmann H, Berg W. 1995. Die Leopoldina im Dritten Reich. Die Elite der Nation im Dritten Reich- Das Verhältnis von Akademien und ihrem wissenschaftlichen Umfeld zum Nationalsozialismus. Acta Hist Leopoldina 22:167-212.

Giles GJ. 1993. Die Tätigkeit Hamburger Hochschullehrer in der NSBewegung. In: Grau G, Schneck P, editors. Akademische Karrieren im Dritten Reich. Beiträge zur Personal- und Berufungspolitik an Medizinischen Fakultäten. Berlin: Pegasus Druck und Verlag. p 83-88.

Goddard S. 2003. A history of gross anatomy: Lessons for the future. Univ Toronto Med J 80:145-147.

Goetzl A, Reynolds RA. 1944. Julius Tandler. A Biography. San Francisco. p 1-63.

Golczewski F. 1988. Kölner Universitätslehrer und der Nationalsozialismus. Personengeschichtliche Ansätze. Köln: Böhlau Verlag.

Greifswald-Vorlesungsverzeichnis: Vorlesungsverzeichnisse der Universität Greifswald 1933 bis 1939.

Grimm M. 2004. Alfred Storch (188-1962): Daseinsanalyse und anthropologische Psychiatrie. Dissertation, Giessen.

Grün B, Hofer H-G, Leven K-H. (eds.) 2002. Medizin und Nationalsozialismus. Die Freiburger Medizinische Fakultät und das Klinikum in der Weimarer Republik und im "Dritten Reich." Frankfurt am Main: Peter Lang Verlag. p 1-544.

Grundmann K, Aumüller G. 1996. Anatomen in der NS-Zeit: Parteigenossen oder Karteigenossen? Das Marburger anatomische Institut im Dritten Reich. Medizinhist J 31:322-357. 
Grüttner M. 2004. Biographisches Lexikon zur nationalsozialistischen Wissenschaftspolitik. Heidelberg: Synchron Wissenschaftsverlag der Autoren. p 1-215.

Grüttner M, Kinas S. 2007. Die Vertreibung von Wissenschaftlern aus den deutschen Universitäten 1933-45. Vierteljahrsh Zeitgesch 55:123-186.

Hammerstein N. 1989. Die Johann Wolfgang Goethe-Universität Frankfurt am Main. Band I: 1914-1950. Neuwied/Frankfurt: Alfred Metzner Verlag. p 1-907.

Hartshorne EY. 1938. The German universities and the government. Ann Am Acad Pol Soc Sci 200:210-234.

Hayek H von. 1940a. Die Läppchen und Septa interlobaria der menschlichen Lunge. Z Anat Entwicklungsgesch 110:405-411.

Hayek H von. 1940b. Über die Präkapillaren, die Arteriolen und die Teilungsstellen der kleinen Arterien in der menschlichen Lunge. Z Anat Entwicklungsgesch 110:587-596.

Heiber H. 1991. Universität unterm Hakenkreuz. Teil I: Der Professor im Dritten Reich. Bilder aus der akademischen Provinz. München: KG Saur. p 1-652.

Heindel W. 1971. Personalbiographien von Professoren und Dozenten des Histologisch-Embryologischen Institutes der Universität Wien im ungefähren Zeitraum von 1848-1968. Dissertation Erlangen-Nürnberg.

Hinrichsen V. 1992. In memoriam des anatomen und embryologen Erich Blechschmidt (1904-1992). Ann Anat 174:479-484.

Hlavácková L, Mísková A. 2001. Otto Grosser (1873-1951) Mediziner. Vom überzeugten Nationalisten zum aktiven Nationalsozialisten. In: Glettler M, Mísková A, editors. Prager Professoren 1938-1945. Zwischen Wissenschaft und Politik. Essen: Klartext Verlag. p 415-428.

Hlavácková L, Svobodny P. 1998. Biographisches Lexikon der Deutschen Medizinischen Fakultät in Prag 1883-1945. Praha: Karolinum. p 1-239.

Hofer HG, Leven KH. 2003. Die Freiburger Medizinische Fakultät im Natinoalsozialismus. Katalog einer Ausstellung des Instituts für Geschichte der Medizin der Universität Freiburg. Frankfurt: Peter Lang. p 1-130.

Höss R, Broad P, Kremer JP. 1984. KL Auschwitz seen by the SS. Selection, elaboration and notes by Bezwinska, Jadwiga and Czech, Danuta. New York: Howard Fertig. p 1-331.

Hossfeld U, John J, Lemuth O, Stutz R. 2003. "Kämpferische Wissenschaft." Studien zur Universität Jena im Nationalsozialismus. Köln: Böhlau Verlag. p 1-1160.

Hubenstorf M. 1987. Österreichische Ärzteemigration Stadler. In: Friedrich, editor. Vertriebene Vernunft I. Emigration und Exil österreichischer Wissenschaft 1930-1940. Wien: Jugend und Volk. p 359-415.

Hubenstorf M. 1989. Medizinische Fakultät 1938-1945. In: Heiss G, Mattl S, Meissl S, Saurer E, Stuhlpfarrer K, editors. Willfährige Wissenschaft; die Universität Wien 1938-1945. Wien: Verlag für Gesellschaftkritik. p 232-281.

Hubenstorf M. 2000. Anatomical science in Vienna, 1938-45. Lancet 355:1385-1386.

Huter F. (ed.) 1970. Hundert Jahre Medizinische Fakultät Innsbruck 1869-1969. II. Teil. Geschichte der Lehrkanzeln, Institute und Kliniken. Innsbruck: Universität Innsbruck.

Jakobi H, Chroust P, Hamann M. 1989. Äskulap und Hakenkreuz. Zur Geschichte der Medizinischen Fakultät in Giessen zwischen 1933 und 1945. Frankfurt: Mabuse-Verlag. p 1-202.

Jansen Ch. 1994. Das Verhältnis der Heidelberger Hochschullehrer zum Nationalsozialismus vor und wahrend der Machtergreifung. In: Kertz W, editor. Hochschule und Nationalsozialismus. Braunschweig: Universitätsbibliothek der Technischen Universität. p 23-35.

Kasten FH. 1991. Unethical Nazi Medicine in Annexed Alsace-Lorraine: The Strange Case of Nazi Anatomist Professor Dr. August Hirt. In: Kent GO, editor. Essays in Modern German History and Archival Policy. Fairfax, Virginia: George Mason University Press. p 173-208.

Kästner I. 1993. Die Auswirkungen der nationalsozialistischen Personalpolitik auf die Medizinische Fakultät der Leipziger Universität. In: Grau G, Schneck P, editors. Akademische Karrieren im "Dritten Reich." Beiträge zur Personal- und Berufungspolitik an Medizinischen Fakultäten. Berlin: Pegasus. p 39-50.
Kater MH. 1974. Das "Ahnenerbe" der SS 1935-1945. Ein Beitrag zur Kulturpolitik des Dritten Reiches. Stuttgart: Deutsche Verlagsgesellschaft. p 1-529.

Kater MH. 1987. The burden of the past: Problems of a modern historiography of physicians and medicine in Nazi Germany. Ger Stud Rev 10:31-56.

Kater MH. 1989. Doctors Under Hitler. Chapel Hill: The University of North Carolina Press. p 1-426.

Kayßer K. 2003. Johannes Sobotta (1869-1945): Leben und Wirken unter besonderer Berücksichtigung seiner Würzburger Zeit. Dissertation, Würzburg. p 1-160.

Kiel-Vorlesungsverzeichnis: Christian-Albrechts Universität Kiel. Personal und Vorlesungsverzeichnisse 1933-1938.

Klee E. 2003. Das Personenlexikon zum Dritten Reich. Wer War was vor und Nach 1945? Frankfurt am Main: S. Fischer. p 1731.

Kolb S, Seithe H. (eds.) 1998. Medizin und Gewissen. 50 Jahre nach dem Nürnberger Ärzteprozess-Kongressdokumentation. Frankfurt am Main: Mabuse-Verlag. p 1-476.

Koops T. 2005. Auf den Spuren der Reichsuniversitäten Posen und Strassburg im Bundesarchiv. In: Bächler C, Igersheim F, Racine $P$, editors. Les Reichsuniversitäten des Strasbourg et de Poznan et les resistances universitaires 1941-1944. Strassbourg: Presse Universitaires des Strasbourg. p 17-34.

Körting W. 1968. Die Deutsche Universität in Prag. Die letzten hundert Jahre ihrer medizinischen Fakultät. Schriftenreihe der Bayerischen Landesärztekammer. Band 11. München: Richard Pflaum Verlag. p 1-300.

Kudlien F. 1985. Ärzte im Nationalsozialismus. Köln: Kiepenheuer und Witsch. p 1-311.

Kühnel W. 1989. 100 Jahre anatomische Gesellschaft. Verh Anat Ges 82(Suppl 64):31-75.

Lachman E. 1977. Anatomist of infamy: August Hirt. Bull Hist Med 51:594-602.

Lang H-J. 2007. Die Namen der Nummern. Wie es gelang, die 86 Opfer eines NS-Verbrechens zu identifizieren. Überarbeitete Ausgabe. Frankfurt am Main: S. Fischer Verlag. p 1-303.

Lanz T von. 1950. Professor Dr. Harry Marcus zum 70. Geburtstag. Münch Med Wochenschr 92:459-461.

Lawrynowicz K. 1999. Albertina. Zur Geschichte der Albertus-Universität zu Königsberg in Preussen. Berlin: Duncker und Humblot. p 1-519.

Lichtenberger-Fenz B. 1989. Österreichs Universitäten und Hochschulen: Opfer oder Wegbereiter der nationalsozialistischen Gewaltherrschaft? Am Beispiel der Universität Wien. In: Heiss G, Mattl S, MeissI S, Saurer E, Stuhlpfarrer K, editors. Willfährige Wissenschaft. Die Universität Wien 1938-1945. Wien: Verlag für Gesellschaftkritik. p 3-15.

Lifton RJ. 1986. Ärzte im Dritten Reich. German Edition 1998. Berlin: Ullstein Buchverlag GmbH\&Co KG. p 1-656.

Lippert H. 1973. Titus W.-H. Ritter von Lanz. 1897-1967. Acta Anat $84: 465-474$

Lippman L. 2009. Life Sentences. New York: Harper Collins publishers. p 157.

Lüddecke A. 1995. Der "Fall Saller" und die Rassenhygiene. Eine Göttinger Fallstudie zu den Widersprüchen sozialbiologistischer Ideologiebildung. Marburg: Tectum Verlag. p 1-119.

Malina P, Spann G. 1999. Das Senatsprojekt der Universität Wien "Untersuchungen zur Anatomischen Wissenschaft in Wien 19381945." Wien Klin Wochenschr 111:743-753.

Masters BR. 2008. History of the optical microscope in cell biology and medicine. Encyclopedia of Life Sciences (ELS). Chichester: Wiley. DOI: 10.1002/9780470015902.a0003082. p 1-8.

Merinsky J. 1980. Die Auswirkungen der Annexion Österreichs durch das Deutsche Reich auf die Medizinische Fakultät der Universität Wien im Jahre 1938. Biographien entlassener Professoren und Dozenten. Phil. Dissertation, Wien.

Mitscherlich A, Mielke F. 1947. Das Diktat der Menschenverachtung. Heidelberg: Verlag Lambert Schneider. p 1-175.

Mitscherlich A, Mielke F. 1960. Medizin ohne Menschlichkeit. Dokumente des Nürnberger Ärzteprozesses. Frankfurt: Fischer Taschenbuch Verlag. p 1-393. 
Mitscherlich A, Mitscherlich M. 1977. Die Unfähigkeit zu trauern. Grundlagen kollektiven Verhaltens. 2nd Ed. München: Piper. p $1-383$.

Mörike KD. 1988. Geschichte der Tübinger Anatomie. Tübingen: JCB Mohr (Paul Siebeck). p 1-188.

Mühlberger K. 1998. Enthebungen an der medizinischen Fakultät 1938-1945. Professoren und Dozenten. Wien Klin Wochenschr 110:115-120.

Müller-Hill B. 1984. Tödliche Wissenschaft. Reinbek bei Hamburg: Rowohlt Taschenbuch Verlag. p 1-188.

Müller-Hill B. 2004. Reflections of a German Scientist. Catalogue of the Exhibit: Deadly Medicine: Creating the Master Race, United States Holocaust Museum. Chapel Hill: University of North Carolina Press. p 185-199.

Müller-Wille M. 1991. Europäische Universitäten 1665-1990. Rektorat der Universität Kiel: 325 Jahre Christian-Albrechts-Universität zu Kiel. Jubiläumsfestakt am 15. Kiel: G+D Grafik und Druck GmbH. p 31-82.

Münch H-G. 1978. Das anatomische Institut in Würzburg von 19251966. Dissertation, Würzburg.

München-Vorlesungsverzeichnis: Vorlesungs und Personalverzeichnisse WS 1932/33-WS 1944/45.

Münster-Vorlesungsverzeichnis: Personal und Vorlesungsverzeichnisse der Westfälischen Wilhelms-Univesität Münster 19321939.

Mussgnug D. 1988. Die vertriebenen Heidelberger Dozenten. Zur Geschichte der Ruprecht-Karls-Universität nach 1933. Heidelberg: Carl Winter. p 1-300.

Neander J. 2006. The Danzig Soap Case: Facts and Legends around "Professor Spanner" and the Danzig Anatomic Institute 19441945. Ger Stud Rev 29:63-86.

Neugebauer W, Schwarz P. 2004. Der Wille zum aufrechten Gang. Offenlegung der Rolle des BSA bei der gesellschaftlichen Integration ehemaliger Nationalsozialisten. Endbericht fuer das Dokumentationsarchiv des Österreichischen Widerstandes (DOeW) vom 21. URL: http://blatt.htu.tugraz.at/hintergrund/ ?doc $=$ bsa041221 [Accessed March 2009].

Noack T. 2007. Begehrte Leichen. Der Berliner Anatom Hermann Stieve (1886-1952) und die medizinische Verwertung Hingerichteter im Natinoalsozialismus. Med Ges Gesch 26:9-35.

Oberkofler G, Goller P. (eds.) 1999. Die medizinische Fakultät Innsbruck. Faschistische Realität (1938) und Kontinuität unter postfaschistischen Bedingungen (1945). Eine Dokumentation. Innsbruck. p 1-210.

Oehler-Klein S. (ed.) 2007. Die Medizinische Fakultät der Universität Giessen im Nationalsozialismus und in der Nachkriegszeit: Personen und Institutionen, Umbrüche und Kontinuitäten. Stuttgart: Franz Steiner Verlag. p 1-632.

Ortmann R. 1986. Die jüngere Geschichte des anatomischen Instituts der Universität Köln 1919-1984. Köln: Böhlau Verlag. p 1136.

Piotrowski B. 1984. Die Rolle der "Reichsuniversitäten" in der Politik und Wissenschaft des hitlerfaschistischen Deutschlands. Universities during World War II. Materials of the International Symposium held at the Jagiellonian University on the anniversary of "Sonderaktion Krakau," Crakow October 22-24, 1979. Zeszyty naukowe Uniwersytetu Jagiellonskiego. Prace historyczne = Universitas Jagellonica Cracoviensis Acta scientiarum litterarumque. Schedae historicae DCXLIII (72):66-486.

Platen-Hallermund A. 1948. Die Tötung Geisteskranker. Heidelberg: Verlag der Frankfurter Hefte. p 1-131.

Politzer G. 1954. Alfred Fischel (1868-1938). Anat Anz 100:291300.

Pressac J-C. 1985. The Struthof Album: Study of the Gassing at Natzweiler-Struthof of 86 Jews Whose Bodies Were to Constitute a collection of skeletons. A Photographic Document. New York: The Beate Klarsfeld Foundation. p 1-88.

Proctor RN. 1988. Racial Hygiene. Medicine under the Nazis. Cambridge: Harvard University Press. p 1-414.

Redies C, Viebig M, Zimmermann S, Fröber R. 2005. Origin of corpses received by the anatomical institute at the University of Jena during the Nazi regime. Anat Rec B New Anat 285:6-10.
Ribhegge W. 1985. Geschichte der Universität Münster: Europa in Westfalen. Münster: Verlag Regensberg. p 1-251.

Rothmaler Ch. 1990. Gutachten und Dokumentation ueber das Anatomische Institut des Universitätskrankenhauses Eppendorf der Universität Hamburg 1933-1945. "1999," Zeitschr Sozialgesch des 20. u 21. Jhd 2:78-95.

Rothschuh KE. 1957. Kleine Geschichte der medizinischen Fakultät der Universität Münster Westfalen. Münster: Aschendorffsche Buchdruckerei. p 1-66.

Rüther M. 1997. Ärztliches Standeswesen im Nationalsozialismus 1933-1945. In: Jütte R, editor. Geschichte der deutschen Ärzteschaft. Köln: Deutscher Ärzte-Verlag. p 143-193.

Sablik K. 1983. Julius Tandler. Mediziner und Sozialreformer. Eine Biographie. Wien: Verlag A. Schendl. p 1-389.

Saller K. 1961. Die Rassenlehre des Nationalsozialismus in Wissenschaft und Propaganda. Darmstadt: Progress-Verlag. p 1-180.

Schafft G. 2004. From Racism to Genocide: Anthropology in the Third Reich. Urbana and Chicago: University of Illinois Press. p 1-297.

Schagen U. 2005. Die Forschung an menschlichen Organen nach "plötzlichem Tod" und der Anatom Hermann Stieve (18861952). In: Bruch R vom, Schaarschmidt R, editors. Die Berliner Universität in der NS-Zeit. Band II: Fachbereiche und Fakultäten. Stuttgart: Franz Steiner Verlag Wiesbaden GmbH. p 35-54.

Schagen U. 2008. Wer wurde vertrieben? Wie wenig wissen wir? Die Vertreibungen aus der Berliner Medizinischen Fakultät 1933. Ein Überblick. In: Schleiermacher S, Schagen U, editors. Die Charité im Dritten Reich. Zur Dienstbarkeit medizinischer Wissenschaft im Nationalsozialismus. Paderborn: Ferdinand Schöningh. p 51-66.

Scheiblechner P. 2001. 1200 Wissenschaftler der "östereichischen" medizinischen Fakultäten und deren Mitgliedschaft bei NS-Teilorganisationen. In: Freidl W, Kernbauer A, Noack RH, Sauer W, editors. Medizin und Nationalsozialismus in der Steiermark. Innsbruck: Studienverlag Innsbruck. p 170-190.

Scheiblechner P. 2002. "...Politisch ist er einwandfrei..." Kurzbiographien der an der Medizinischen Fakultät der Universität Graz in der Zeit von 1938 bis 1945 tätigen Wissenschaftlerinnen. Graz: Akademische Druck-u.Verlagsanstalt.

Schierhorn H. 1986. Mitglieder der Anatomischen Gesellschaft im antifaschistischen Exil. Verh Anat Ges 80:957-963.

Schmidt W. 1993. Leben an Grenzen. Autobiographischer Bericht eines Mediziners aus dunkler Zeit. Baden-Baden: Suhrkamp/ Nomos Verlagsgesellschaft. p 1-304.

Schneck P. 1993. Die Berufungs- und Personalpolitik an der Greifswalder Medizinischen Fakultät zwischen 1933 und 1945. In: Grau G, Schneck P, editors. Akademische Karrieren im Dritten Reich. Beiträge zur Personal- und Berufungspolitik an Medizinischen Fakultäten. Berlin: Pegasus Druck und Verlag. p 51-62.

Schneider H. 1944. Zur Anatomie des Bewegungsapparates. Z Anat Entwicklungsgesch 113:187-203.

Schönhagen B. 1992. Das Gräberfeld X auf dem Tübinger Stadtfriedhof. Die verdrängte 'Normalität" nationalsozialistischer Vernichtungspolitik. In: Peiffer J, editor. Menschenverachtung und Opportunismus. Tübingen: Zur Medizin im Dritten Reich. Attempto. p 69-92.

Schottländer R. 1988. Verfolgte Berliner Wissenschaft. Ein Gedenkwerk. Berlin: Edition Hentrich. p 127-130.

Schuhmacher G-H, Wischhusen H. 1970. Anatomia Rostochensis: Die Geschichte der Anatomie an der 550 Jahre alten Universität Rostock. Berlin: Akademieverlag. p 1-333.

Seidler E. 2000. Kinderärzte 1933-1945: Entrechtet- GeflohenErmordet. Bonn: Bouvier. p 1-494.

Seidler E, Leven K-H. 2007. Die Medizinische Fakultät der AlbertsLudwigs-Universität Freiburg im Breisgau. Grundlagen und Entwicklungen. Freiburg: Verlag Karl Alber. p 1-885.

Steegmann R. 2005a. La Faculté de Médicine de la Reichsuniversität de Strassbourg et las expérimentations médicales au KL-Natzweiler. In: Bächler Ch, Igersheim F, Racine P, editors. Les Reichsuniversitäten des Strasbourg et de Poznan et les Resistances Universitaires 1941-1944. Strasbourg: Presse Universitaires des Strasbourg. p 143-158.

Steegmann R. 2005b. Struthof. Le KL-Natzweiler et ses Kommandos: Une Nébuleuse Concentrationnaire des deux côtés du Rhin 1941-1945. Strassbourg: Éditions de La Nuée Bleue. p 1-489. 
Thom A. 1990. Von 1933-1945. In: Käestner, Ingrid; Thom, Achim: 575 Jahre Medizinische Fakultät der Universität Leipzig. Leipzig: Johann Ambrosius Barth. p 162-202.

Tilitzki Ch. 2006. Die Albertus-Universität Königsberg im Umbruch von 1932-1934. In: Pletzin Ch, editor. Vorposten des Reiches? Ostpreussen 1933-1945. München: Meidenbauer Verlagsbuchhandlung. p 41-76.

Toellner R. 1980. Medizin in Münster. Dollinger, Heinz: Die Universität Münster 1780-1980. Münster: Aschendorff. p 285-308.

Tonutti E. 1957. Das Anatomische Institut. In: Herzog, Georg: Zur Geschichte der Akademie fuer Medizinische Forschung und Fortbildung (Medizinische Fakultät). p 31-34. URL: http://geb.unigiessen.de/geb/volltexte/2006/3046/pdf/HerzogGeschichte-1957. pdf [accessed March 2009].

Uhlig R. (ed.) 1991. Vertriebene Wissenschaftler der ChristianAlbrechts-Universität zu Kiel (CAU) nach 1933. Frankfurt am Main: Peter Lang Verlag. p 1-158.

UhImann A. 2002. Die Freiburger Krankengymnastik-Schule: von der Schulgründung 1935 bis zum Ende des Dritten Reiches. In: Grün B, Hofer H-G, Leven K-H, editors. Medizin und Nationalsozialismus. Die Freiburger Medizinische Fakultät und das Klinikum in der Weimarer Republik und im "Dritten Reich." Frankfurt am Main: Peter Lang Verlag. p 262-285.

Unger M. 1998. Ferdinand Wagenseil (1887-1967). Integrer Forscher und Bewahrer der Medizinischen Fakultät Giessen. Giessen: Wilhelm Schmitz Verlag. p 1-182.

Universität Innsbruck. (ed.) 1992. Die Medizinische Fakultät der Leopold-Franzens-Universität Innsbruck. Innsbruck: R. Kudeler OHG. p 1-123.

Viebig M. 2002. Zu Problemen der Leichenversorgung des Anatomischen Institutes der Universität Halle vom 19. bis Mitte des 20. Jahrhunderts. In: Beiträge zur Geschichte der Martin-LutherUniversität 1502-2002. Halle: MDV, Mitteldeutscher Verlag Halle. p 117-146.

Vieten B. 1982. Medizinstudenten in Münster. Universität und Studentenschaft 1905-1945. Köln: Pahl-Rugenstein Verlag. p 1 360.

Vieten B. 1983. Medizinstudenten und Medizinische Fakultät in Münster im "Dritten Reich." In: Thien HG, Wienold H, editors. Münster- Spuren aus der Zeit des Faschismus. Zum 50. Jahrestag der nationalsozialistischen Machtergreifung. Münster: Edition Westfälisches Dampfboot. p 201-213.

Volbehr F, Weyl R. 1956. Professoren und Dozenten der ChristianAlbrechts-Universität zu Kiel 1665-1954. Kiel: Ferdinand Hirt. p $1-293$.

Wallraff J. 1959. Wilhelm Blotevogel. Anat Anz 107:92-96.

Waltenbacher T. 2008. Zentrale Hinrichtungsstätten. Der Vollzug der Todesstrafe in Deutschland von 1937-1945. Scharfrichter im Dritten Reich. Berlin: Zwilling. p 1-263.
Walther PT. 2008. Entlassungen und Exodus: Personalpolitik an der Medizinischen Fakultät und in der Charité 1933. In: Schleiermacher S, Schagen U, editors. Die Charité im Dritten Reich. Zur Dienstbarkeit medizinischer Wissenschaft im Nationalsozialismus. Paderborn: Ferdinand Schöningh. p 37-50.

Wechsler P. 2005. La Faculté des Médicine de la "Reichsuniversität Strassburg" (1941-1945) a I'heure nationale-socialiste. Dissertation. Freiburg im Breisgau. p 1-261.

Weckbecker A. 1985. Gleichschaltung der Universität? Nationalsozialistische Verfolgung Heidelberger Hochschullehrer aus rassischen und politischen Gründen. In: Auch eine Geschichte der Universität Heidelberg. Mannheim: Edition Quadrat. p 273-292.

Wegner RN. 1956. Die Geschichte des anatomischen Instituts und Museums der Universität Greifswald. Festschrift zur 500-Jahrfeier der Universität Greifswald 17.10.56. p 282-295.

Weingart P, Kroll J, Bayertz K. 1988. Rasse, Blut und Gene. Geschichte der Eugenik und Rassenhygiene in Deutschland. Frankfurt am Main: Suhrkamp. p 1-746.

Wendehorst A. 1993. Geschichte der Friedrich-Alexander-Universität Erlangen-Nürnberg 1743-1993. München: Verlag C.H. Beck. p 1-296.

Wien-Vorlesungsverzeichnis: Öffentliche Vorlesungen an der Universität zu Wien. Vorlesungsverzeichnisse 1937/38.

Winkelmann A, Schagen U. 2009. Hermann Stieve's clinical-anatomical research on executed women during the "Third Reich." Clin Anat 22:163-171.

Wittern R. 1993. Aus der Geschichte der medizinischen Fakultät. In: Kössler $\mathrm{H}$, editor. 250 Jahre Friedrich-Alexander-Universitaet Erlangen-Nürnberg. Festschrift. Erlangen: Verlagsdruckerei Schmidt. p 315-420.

Wittstadt K. 1982. Die Katholisch-Theologische Fakultät der Universität Würzburg während des Dritten Reiches. In: Baumgart $\mathrm{P}$ editor. Vierhundert Jahre Universität Würzburg: Eine Festschrift. Neustadt an der Aisch: Degener und Co. p 399-436.

Wróblewska T. 2000. Die Reichsuniversitäten Posen, Prag und Strassburg als Modell Nationalsozialistischer Hochschulen in den von Deutschland besetzten Gebieten. Torun: Marszalek. p 1308.

Ziesche KT. 1943. Zur Histologie des Tuber cinereum des Menschen. Z Zellforsch 33:143-150.

Zimmermann S. 2000. Die medizinische Fakultät der Universität Jena während der Zeit des Nationalsozialismus. Berlin: Verlag für Wissenschaft und Bildung. p 1-225.

Zimmermann V. 1991. Die Medizin in Göttingen während der Nationalsozialistischen Diktatur. Würzburger medizinhistorische Mitteilungen. Band 9. p 393-416.

Zitzlsperger S. 1944. Neue Methoden zur Untersuchung der Reaktionskinetik histologischer Färbungen. Z Anat Entwicklungsgesch 113:164-173. 